DOI: doi.org/10.18372/38236

UDC: $667.637 .22: 629.7 .065(045)$

\title{
2.5 INFLUENCE OF ELECTROMAGNETIC TREATMENT OF FUELS AND OILS ON THE FORMATION OF WEAR RESISTANCE OF FRICTION PAIRS
}

\author{
Igor Trofymov, Mykhailo Svyryd, Olena Matveyeva, Oleksandr Sydorenko
}

The studies referred to in the article relate to the engineering industry. In connection with the sharp rise in the cost of natural resources, increasing the performance properties of lubricants (L) becomes an urgent scientific and technical problem. Therefore, the issue of improving the operating properties of working fluids, in particular, by performance of electromagnetic field (EMF) or magnetic field (MF), is one of the components when considering priority areas to ensure the reliability of motor equipment and friction units.

Modern technic is equipped with complex hydraulic systems that perform important functions in the control of aircraft and ground equipment. The reliability of the fuel and hydraulic units largely depends on the performance of precision friction pairs. As a result of increased wear, destruction and jamming of friction pairs, failures of hydraulic units arise, and it becomes necessary to replace worn parts systematically. The most common defects include the jamming of plunger, plate and spool pairs, the destruction of rolling bearings, wear of the grommets of plungers, etc. The specificity of these friction pairs requires a critical approach in the matter of using to them the existing concepts of the relative influence of lubricants, the mechanical properties of materials, the roughness of the mating surfaces, the speed of their relative movement.

The purpose of the work is to increase the reliability of fuel systems parts by eliminating the causes of unit failures, analyzing the structural, technological and operational factors that determine their performance, and developing measures on this basis to ensure trouble-free friction pairs. In continuation of the research, the purpose of the work was also to study the change in the energy state of M10G2k oil under the influence of MF by passing a white light beam through it and determining the energy aspects of the interaction of oil with MF, which will allow adjusting the wear rate of friction surfaces, treated in MF media.

The most important condition for the implementation of reliability, embedded in the design of fuel-hydraulic units, is to improve the performance properties of operating fluids. Today, the requirements for the modes and operation properties of the fuels and lubricants determine the need to increase their anti-wear properties and search for new directions and methods for this.

In this work the electrophysical treatment is proposed to improve the operating properties of fuels, which occurs when they are passed through an electromagnetic or magnetic field.

Analysis of the literature [1-3] shows the interest of the authors in experimental and theoretical development of improving the antiwear properties of precision friction pairs and studies of the influence of the electromagnetic field on the state and property of working fluids.

One of the ways to extend the service life and restore tribo-triggers is tribomodification of friction surfaces due to the formation of metal-containing films, through the use of lubricants that are under the action of a magnetic field.

As it is known, lubricants, treated with MF possess high antifriction and wear-resistant properties [1], therefore they are used for lubricating magnetic bearings, gears, etc.

Nowadays, considerable attention is paid to research on the modification of motor oil by treating it with physical fields, the results of which are shown in the works of many scientists, namely, I.A. Portnoy, E.M. Lisikova, N. A. Pivovarova, E.S. Wenzel, L.I. Pogodaeva, S.V. Putintseva et al. [4-6].

In [7], it was shown that one of the ways to improve the operative properties of fuels is their electrophysical processing, which occurs when the working fluid is passed through a magnetic field while simultaneously applying a high-frequency electromagnetic field with a frequency equal to the 
proton precession frequency in a given magnetic field. The authors found that the electrophysical treatment of diesel fuel reduces the hourly and specific fuel consumption by $2 \ldots 4 \%$ at all crankshaft rotational speeds, while the greatest effect was observed at idle (hourly fuel consumption decreased by $8 \ldots 12 \%$ ).

A number of researchers $[8,9]$ proved that when treating a fuel with an electric field, its drops, in addition to the molecular forces that determine their strength, also have aerodynamic and electric forces directed in the opposite direction. Reducing the surface tension of the droplet leads to a thinner dispersion of the liquid, improving combustion and, as a consequence, reducing the toxicity of exhaust gases.

The authors of [10] conducted research on the effects of the electromagnetic field on aviation fuel in order to extend the service life of rolling bearings on the fuel flow meter sensors. The authors established the effect of electromagnetic treatment on the antiwear properties of hydrocarbon interfaces. In their opinion, one of the features of chemical conjugations in organic compounds is the spatial orientation, in which the molecule acquires a certain geometric structure, the chemical bonds in it are covalent in nature and are relatively easily polarized. The shift of electrons in molecules, caused by the mutual influence on atoms, actively influences the physicochemical properties of hydrocarbons.

The quantum mechanics says that the greater the frequency of the light flux, or its change from red to violet, the greater its energy [11]. Therefore, a change in the color of a substance is an energy indicator in the formation of the internal state of hydrocarbon SS, which can be changed by the external influence of a magnetic field.

To understand the experiments conducted by us and described below, it is necessary to select something from the theory of magnetism: a magnet is a permanent source of photons; a photon is a movable discrete transverse electromagnetic disturbance, which consists of an electric quantum and a magnetic flux quantum and represents an excited state of the field. A photon that moves forms partial electromagnetic waves, which, according to Huygens' principle, due to interference, are not emitted, but move together with the photon as a single entity, representing a package of partial waves as a train. If we add two such quanta, we get a quantum of double energy $(\mathrm{E}=\mathrm{h} .2)$, which is usually called a photon. The more quanta in a photon, the more powerful it is, since a photon consists of a larger number of minimal portions of energy. Although the photons have no mass, they have different energies. If we see a red ray of light, this means that the photons of which it is composed have energy at the level of 1.68-1.98 eV.

Planck's quantum hypothesis was that for elementary particles, any energy is absorbed or released only in discrete portions. These portions consist of an integer number of quanta with an energy proportional to the frequency $v$ with a proportionality coefficient determined by the formula: $E=h \cdot v=h \omega$, where: $\mathrm{h}$ is the Planck constant. Thus, a change in the color of light is the change in photon energy.

The color of the oil when light passes through it in the MP changes in the direction of an increase in frequency (in color from yellow to green), the frequency increases from $510 \mathrm{THz}$ to 600 $\mathrm{THz}$, which means that the photon energy that passes through the oil increases and thereby increases its activation.

In the presence of MF, the quantum part, which has a spin magnetic moment, receives additional energy $\Delta E=-\vec{\mu} \cdot \vec{B}$ proportional to its magnetic moment $\vec{\mu}$ (Zeeman effect). Acquired energy leads to the removal of atomic states by the magnetic quantum number $m_{j}$ and the splitting of atomic lines. However, the authors of [11] experimentally confirmed that the quanta of the electromagnetic radiation flux have a field structure, that is, they consist of electric and magnetic fluxes and, accordingly, all laws of electrodynamics apply to them. According to electrodynamics, in an electromagnetic wave, the energy of an electric flux is always equal to the energy of a magnetic flux. Under the conditions of physicochemical interactions of lubricants with a metal 
surface under friction, besides adding chemicals to the lubricants, physical methods are known for its processing with sound and ultrasonic waves, irradiation with light of different wavelengths, etc.

The study of the influence of magnetic fields on liquid environment was carried out by the authors of [12], who determined the influence of external magnetic fields on the transfer processes in ferrosuspensions. The researchers argue that such a powerful influence is explained by the structure formation in a fluid-dynamic system as a result of the dipole-dipole interaction of ferromagnetic particles and the orientation of the structure elements along the MP force lines. At the same time, the geometry and magnitude of the magnetic field, the concentration and size of particles, their magnetic properties and other factors affect the transfer processes. The rheological properties of ferrosuspension, namely plasticity and effective viscosity (magnetorheological effect), are most intensively changed. Also, in [12], the results of studies of the magnetorheological effect are summarized - a sharp change in mechanical properties (viscosity, plasticity, elasticity) under the action of a magnetic field. It is shown that the electrical and magnetic permeability of liquids varies considerably.

The method of treating fuel and lubricants with an electric field has been improved, which makes it possible to increase the antiwear properties of fuels and oils several times [13, 14].

In this regard, the question of the influence of electrophysical treatment of fuels on the formation of wear resistance of friction pairs of fuel systems remains open.

In order to determine the influence of the magnetic field on the physicochemical and operational properties of hydrocarbon fuels, a method for treating fuel [14] and a filter activator fuel [15] were developed, the essence of which is that due to the influence of electromagnetic field pulses generated around coils wires of high voltage during the passage of high-voltage pulses of electric current from a source of high voltage pulses through it, frequency pulsed electromagnetic processing of fuel is carried out, as a result of which the fuel is activated, in particular, the physicochemical properties of the fuel are improved.

Processing (activation) of fuel by electromagnetic field pulse lines causes an improvement in fuel performance such as pumpability, evaporation, flammability, flammability, as well as an improvement in fuel energy characteristics such as volatility, a decrease in flammability temperature, and an increase in combustion stability.

Electromagnetic pulses provide fragmentation, changes in the structure and configuration of fuel molecules, weakening the bonds between them, reducing their surface tension. In addition, some fuel molecules are charged for a sufficient period of time, as a result of which they more actively combine with the oxidizing agent - oxygen. This contributes to a more optimal mixing of the air-fuel mixture in the combustion chamber and, as a consequence, an increase in the completeness of combustion.

It was found that the fuels subjected to this electromagnetic treatment were characterized by a decrease in viscosity and density, and for 12 hours after the treatment, an increase in the acidity index was observed.

«TC-1» jet fuel was selected as a working fluid, which has low anti-wear and rheological properties and provides friction at the nodes. Also, the gasoline A-92, which acts as fuel for cars, trucks and special vehicles, was amenable to electrophysical processing. The tests were carried out using the finger-plane friction scheme; material of samples WX15- photographic glass $\vartheta=0.30$; $0.630 \mathrm{~m} / \mathrm{s}, \mathrm{P}=5 \mathrm{~N}$. The sample finger size: diameter $-4 \mathrm{~mm}$, length $-25 \mathrm{~mm}$. Sample No. 1 and No. 3 worked in the base (not processed) environment of aviation fuel «TC-1» and gasoline A-92, respectively. Sample No. 2 and No. 4 worked in the environment of aviation fuel «TC-1» and, respectively, gasoline A-92, treated with fields for 1 hour at a voltage of $U=32,000 \mathrm{~V}$ and field strength $\mathrm{E}=4.106 \mathrm{~V} / \mathrm{m}$ Sample No. 5 worked in the environment of gasoline A-92, treated with EMF, after 24 hours of the relaxation period. The mass of prototypes was measured on an analytical balance of increased accuracy "ADV-200 2Kl". 
Given these changes in the physicochemical properties of fuels, it would be legitimate to assume that similar changes in the anti-wear properties of the treated fuels are possible, which are an important performance indicator. In this regard, to study the effect of electrophysical treatment of fuels and low-viscosity liquids on the change in antiwear properties and friction coefficient, a complex was used to study the tribological characteristics of fuels and lubricants, developed by the authors [16]. The technical conditions of the complex make it possible to take photographic images and video footage of surface transformations in a dynamic mode.

The results of the experiments are given in Table. 1. From Table 1 it can be seen that under the same experimental conditions and with the same distance traveled (in the medium of jet fuel $12 \mathrm{~km}$, in gasoline $-3 \mathrm{~km}$ ) for sample No. 1, the amount of wear after mass was $0.0013 \mathrm{~g}$, for sample No. $2-0.0003 \mathrm{~g}$, the difference was -0.001 grams. For sample number 2 , the difference over the mass of $0.001 \mathrm{~g}$ was only after $22 \mathrm{~km}$ of the distance traveled. For sample No. 3, the amount of wear after mass was $0.0032 \mathrm{~g}$, for sample No. 4, $0.0012 \mathrm{~g}$, the difference was 0.002 grams. For sample number 5 , the difference was -0.0025 grams.

Table 1

The results of experiments conducted on the complex to study the tribological characteristics of fuels and lubricants

\begin{tabular}{|c|c|c|c|c|}
\hline $\begin{array}{c}\text { Sample } \\
\text { Number/Environment }\end{array}$ & Mass, $\mathrm{m}, \mathrm{g}$ & Distance, $\mathrm{S}, \mathrm{km}$ & Friction velocity, $\vartheta, \mathrm{m} / \mathrm{s}$ & Load, P, N \\
\hline \multirow{2}{*}{$\begin{array}{l}\text { Sample № } 1 \\
/ \text { «TC-1» }\end{array}$} & 2,1478 & 0 & \multirow{5}{*}{0,630} & \multirow{5}{*}{5} \\
\hline & 2,1465 & 12 & & \\
\hline \multirow{3}{*}{$\begin{array}{l}\text { Sample № } 2 \\
\text { / «TC-1»EMF }\end{array}$} & 2,1539 & 0 & & \\
\hline & 2,1536 & 12 & & \\
\hline & 2,1529 & 22 & & \\
\hline \multirow{2}{*}{$\begin{array}{l}\text { Sample № } 3 \\
\text { / A-92 }\end{array}$} & 2,1575 & 0 & \multirow{2}{*}{0,330} & \multirow{2}{*}{5} \\
\hline & 2,1543 & 3 & & \\
\hline \multirow{2}{*}{$\begin{array}{l}\text { Sample № } 4 \\
\text { / A-92 } 2_{\mathrm{EMF}}\end{array}$} & 2,1543 & 0 & \multirow{4}{*}{0,330} & \multirow{4}{*}{5} \\
\hline & 2,1531 & 3 & & \\
\hline \multirow{2}{*}{$\begin{array}{l}\text { Sample№ } 5 \\
\text { / A-92 } 2 \text { EMF.p. }\end{array}$} & 2,1545 & 0 & & \\
\hline & 2,1520 & 3 & & \\
\hline
\end{tabular}

The results of studies of the friction coefficients of the tribocouples are shown in Fig. 1-2.

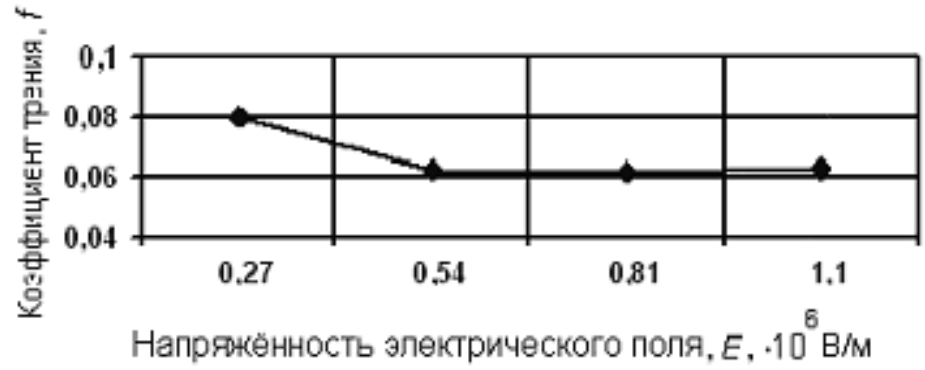

Fig. 1. Dependence of the friction coefficient of steel SHKh15 on the electric field strength at sliding speed $=$ $0.6 \mathrm{~m} / \mathrm{s}$ in «TC-1» jet fuel 


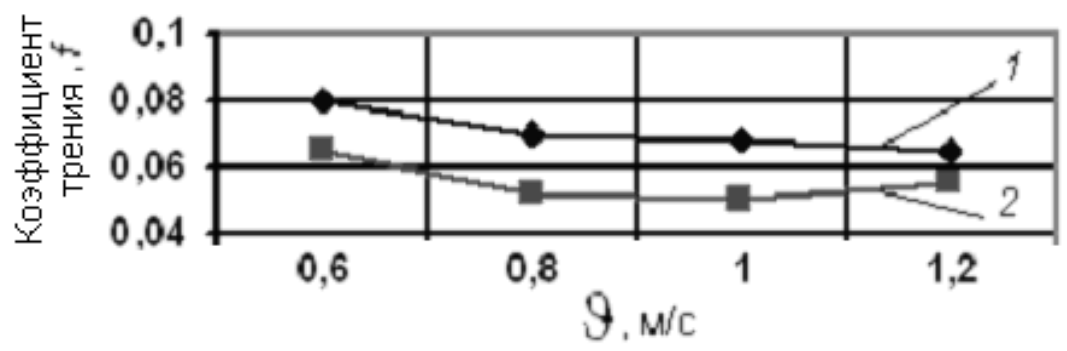

Fig. 2. Dependence of the friction coefficient of steel SHKh15 on the sliding speed at a specific load $\mathrm{P}=$ $5 \mathrm{~kg} / \mathrm{cm}^{2}: 1$ - in the «TC-1» jet fuel in the delivery condition; 2 - in the aviation fuel processed by the EMF for 1 hour at a voltage of $U=32000 \mathrm{~B}$ and field strength $E=4.10^{6} \mathrm{~V} / \mathrm{m}$

It has been established that with an increase in the electric field strength, the coefficient of sliding friction decreases (Fig. 1). This can be explained by an increase in the mobility of parts of molecules, caused by the fragmentation of sedentary large molecules of lubricating media using an electromagnetic field.

A reduction in the friction coefficient of steel SHKh15 with an increase in the sliding speed was established. The friction coefficient during lubrication of the contact with jet fuel «TC-1», treated with an electromagnetic field is 1.3 times less in comparison with the coefficient of friction obtained in «TC-1» in the delivery condition (Fig. 2). The decrease in the friction coefficient can be explained by a decrease in the magnitude of the surface tension of the fuel during its processing by the EMF, which has also been established experimentally.

Optical comparison of the friction surfaces of the samples shows (Fig. 3) that in the case of their operating time at $=0.63 \mathrm{~m} / \mathrm{s}$ and the same friction paths in the «TC-1» jet fuel treated with an electric field, oxidation films begin to form much later and in comparison with $1000 \mathrm{~m}$ of the traversed path of oxidative films is almost not found.

Investigating the surface of samples produced at $\vartheta=0.8 \mathrm{~m} / \mathrm{s}$, after $1000 \mathrm{~m}$ of friction, the subsequent formation and accumulation of oxidative films was detected, after $12000 \mathrm{~m}$ of friction films that occupy a sufficiently large area of friction are clearly visible. But for samples developed in «TC-1» treated with an electromagnetic field after $12000 \mathrm{~m}$ of friction, a sharp decrease in the number of secondary structures and a decrease in their area on the friction surface were found. This gives the right to argue about their destruction and removal of friction from the surface at the specified distance traveled. A similar picture was observed in micrographs of the surface of samples produced at $\vartheta=1.2 \mathrm{~m} / \mathrm{s}$ after $12000 \mathrm{~m}$ of the traversed friction path, and in the case of accumulation in the «TC-1» basic fuel, oxide films look clearly formed and have clear limits for the transition from the secondary structure to the main structure metal. At the same time, for samples developed in the aviation fuel processed by EMF - more subtle and elastic.

Comparing the friction surfaces of the samples (Fig. 4) developed in gasoline treated with EMF at a constant speed $=0.330 \mathrm{~m} / \mathrm{s}$ and load $\mathrm{P}=5 \mathrm{~N}$, it was found that oxidizing films are thinner and more elastic, which fully explains obtaining a lower wear value at the same traversed friction path. On both surfaces, the secondary structures directed behind the movement of friction and at the stage of formation look the same.

After $3000 \mathrm{~m}$ of the path, the films of the sample produced in the EMF-treated gasoline become significantly larger with the length and width, and they also have destroyed areas that alternate with the sections of the films themselves (in comparison with the films of the sample obtained in the base gasoline).

Sample treated in gasoline with an EMF after 24 hours after treatment showed that the films looked completely formed and oriented behind the direction of movement, and the friction surface 
itself is very similar to the friction surface of the sample worked out in the base gasoline with the same path traveled.

Operation time of the samples in the base aviation fuel «TC-1»

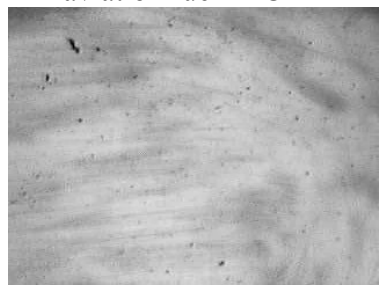

Operation time of samples in the aviation fuel processed by the electromagnetic field «TC-1 $»_{\mathrm{EMF}}$

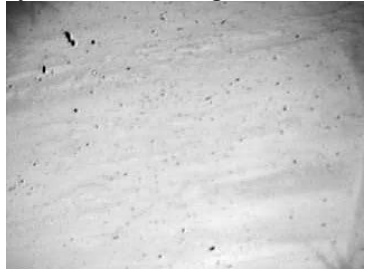

Sample surface through $1000 \mathrm{~m}$ friction path

Sample surface through $1000 \mathrm{~m}$ friction path $\mathcal{Y}=0,63 \mathrm{~m} / \mathrm{s}, P=5 \mathrm{~N}$

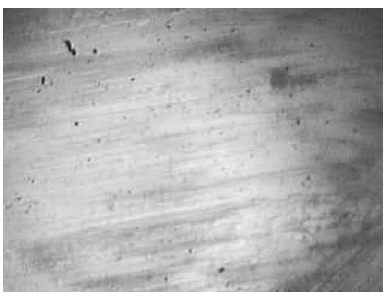

Sample surface through $1000 \mathrm{~m}$ friction path

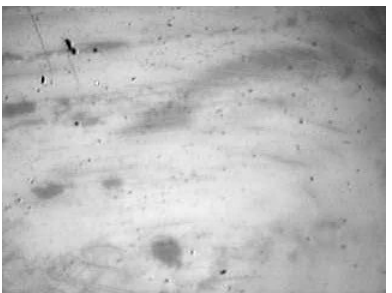

Sample surface through $12000 \mathrm{~m}$ friction path

$$
\mathcal{Y}=0,8 \mathrm{~m} / \mathrm{s}, P=5 \mathrm{~N}
$$

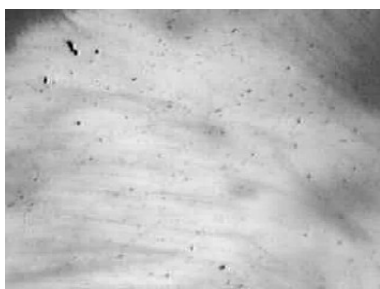

Sample surface through $1000 \mathrm{~m}$ friction path

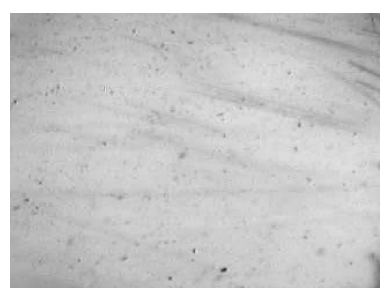

Sample surface through $1000 \mathrm{~m}$ friction path

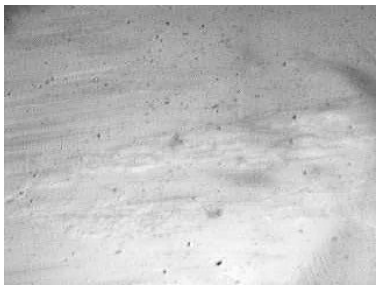

Sample surface through $12000 \mathrm{~m}$ friction path

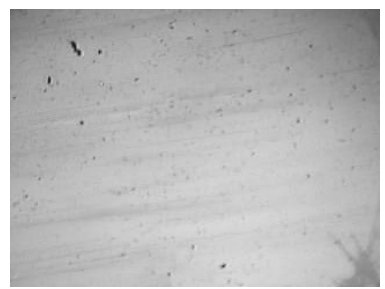

Sample surface through $1000 \mathrm{~m}$ friction path

$$
\mathcal{Y}=1,2 \mathrm{~m} / \mathrm{s}, P=5 \mathrm{~N}
$$

Fig. 3. Micrographs of steel samples ШX15 surfaces; $\times 150$ 
Operation time of the samples in the base fuel A-92

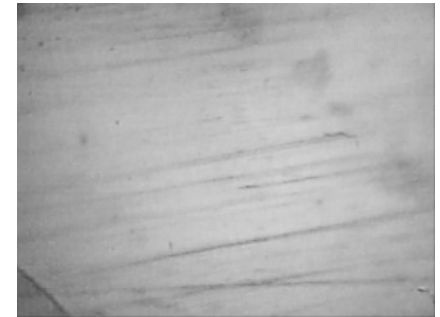

Sample surface through $1000 \mathrm{~m}$ friction path

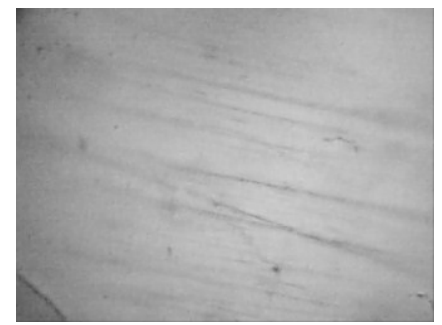

Sample surface through $3000 \mathrm{~m}$ friction path
Operation time of samples in the fuel processed by the electromagnetic field A-92

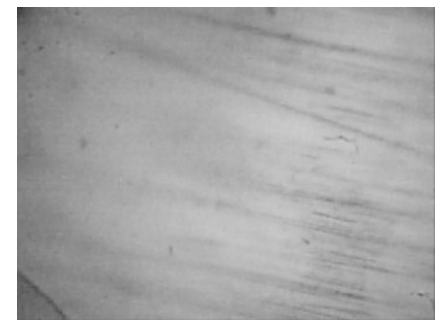

Sample surface through $1000 \mathrm{~m}$ friction path

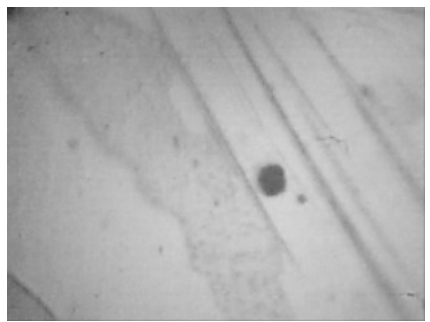

Sample surface through $3000 \mathrm{~m}$ friction path

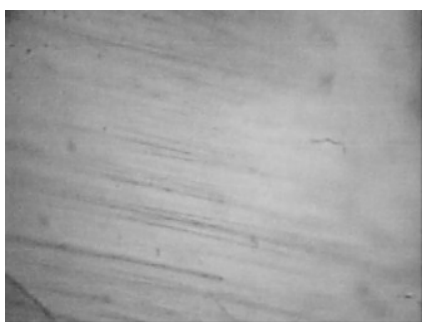

Sample surface through $3000 \mathrm{~m}$ friction path (Operation time of the samples in the gasoline after 24 hours of relaxation)

$$
\mathcal{Y}=\mathbf{0 , 3 3 0} \mathrm{m} / \mathrm{s}, P=5 \mathrm{~N}
$$

Fig. 4. Micrographs of steel samples ШX15surfaces; $\times 150$

To determine the change in the energy parameters of oil in MF, we designed a device for assessing the energy-information state of liquid carbon materials (Fig. 5.), which consists of: a computer for capturing the image of changes in liquid carbon materials 1 ; light sources 2 ; lens for processing light 3 ; permanent magnets 4 , which create a magnetic field for processing liquid SS; dielectric glass capacitance 5 , which is located between the magnetic field and the test material; microscope "MPD-1U11" 6; "Quick Cam Express" cameras 7.

The dielectric glass container 5 is placed between two permanent magnets 4 . Then it is filled with liquid carbon material and placed on the optical axis of the microscope 6 . Then, using a light source 2 and an objective for processing light 3, they pass a beam of white light through the liquid material under study field. Its induction value is $0.3 \mathrm{Tl}$.

Next, using the camera 7 , the image of energy-information changes in liquid carbon materials is processed and recorded, which can be seen on the computer monitor 1. Accordingly, all the necessary experimental results were recorded and stored on electronic device.

Thus, the change in the energy state of the oil depending on the change in its color under the action of a magnetic field was studied, namely, the orange color is characterized by the light energy 
$1.98 \mathrm{eV}$, green $-2.48 \mathrm{eV}$.The essence of the presented technique is to change the frequency of white light, that is, the light that passes through the layer of oil that is in the MF. Each color has its own energy component (see Table. 2).

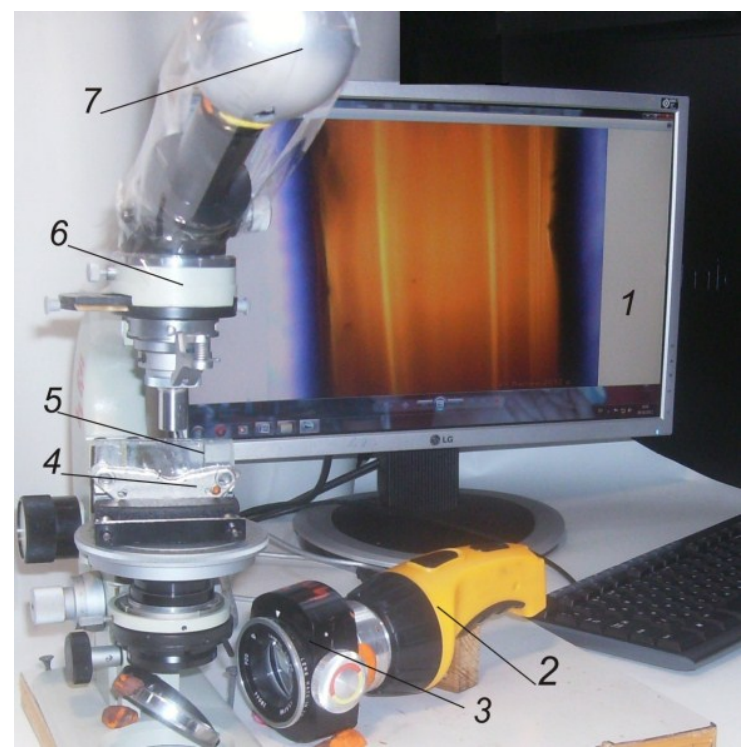

Fig. 5. A device for assessing the energy-information state of liquid carbon materials in a magnetic field: $1-\mathrm{a}$ computer for fixing the image of energy-information changes in liquid carbon materials; 2 - light source; 3 lens for processing light; 4 - permanent magnets; 5 - dielectric glass capacitance; 6 - microscope "MPD-

1U11"; 7 - "Quick Cam Express" camera

Table 2

Energy parameters of light

\begin{tabular}{|c|c|c|c|}
\hline Color & Wavelength range, $\mathrm{nm}$ & Frequency range, THz & Photon energy range, eV \\
\hline Green & $500-565$ & $600-530$ & $2,19-2,48$ \\
\hline Yellow & $565-590$ & $530-510$ & $2,10-2,19$ \\
\hline Orange & $590-625$ & $510-480$ & $1,98-2,10$ \\
\hline
\end{tabular}

The presented methodology for studying changes in the energy state of liquids is characterized by the possibility of monitoring changes in the energy-information state of liquid carbon materials in MF.

The conditions for changing the energy state of the medium are explained by the physical properties of the influence of the magnetic field on the magnets, which are in the composition of the oil and changes in their orientation in space (Fig. 6).

On the basis of the experiment, a beam of white light, which is characterized by a frequency range $(400 \ldots 790 \mathrm{THz})$ and a photon energy $(15.81 \ldots 17.39 \mathrm{eV})$ passes through the layer of the test oil. In the case of passing a beam of light through the oil without the action of the MP (Fig. 2a) after scanning, we obtain the energy of orange color, which has a value $(1.98 \ldots 2.1 \mathrm{eV})$ and a frequency range $(480 \ldots 510 \mathrm{THz})$. This color meets the conditions of the oil, which is located between the poles of the magnet (Fig. 7.) 


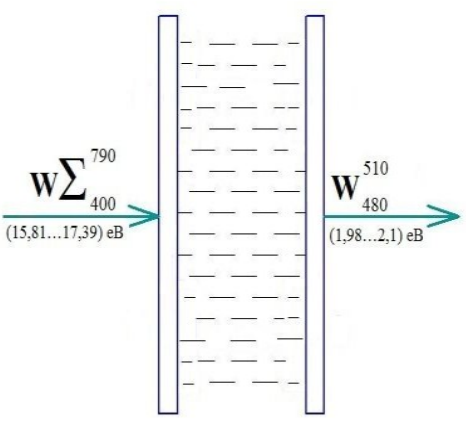

(a)

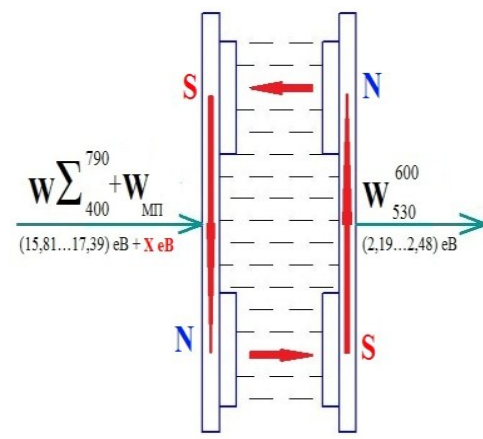

(b)

Fig. 6. The physical content of the experiment: $(a)$ the study of the energy state of the oil M10G2k by passing a beam of white light through it; $(b)$ study of the influence of MP on the energy state of the oil M10G2k by passing a beam of white light through it

In Fig. 7 shows the results of studies of the change in the energy state of motor mineral oil M10G2k in MF. The influence of MF on the change of the state of the environment was determined by the change in color to the lumen. Green color characterizes oil at the poles of a magnet that corresponds to energy $(2.19 \ldots 2.48 \mathrm{eV})$ with the highest energy content. That is, in this position, the oil holds the auxiliary energy of the MF.

The energy component affects the placement of oil dipoles and we believe that they are located along the MF lines, that is, perpendicular to the surface of the magnet. The transition zone, which is located between the poles of the magnet, has an orange color of lower energy $(1.98 \ldots$ $2.1 \mathrm{eV}$ ). Thus, the oil that is located between the poles has the same energy; in our case, we designated it as the initial one (No.0). The transition zones from the initial to the traits (Fig. 7.) N/S No.2 S/N or No.2 (to green) are characteristic of mixed shades of blue-violet and green, which indicates a change in the arrangement of the conglomerates of the environment (Fig. 7.) N/S No.1 $\mathrm{S} / \mathrm{N}$ or No.1. In addition, each condensation has its own energy component, their chaotic location characterizes the preparation for changing the state of the oil, this can be expressed:

$$
\mathrm{W}^{790}{ }_{400}=\mathrm{W}^{510}{ }_{480}+\mathrm{W}_{\text {lfr. }} \text {. }
$$

When studying the influence of MF on the energy state of the oil M10G2k by passing a beam of white light through it (Fig. 6b), in addition to the energy of white light, the energy of MF $\left(\mathrm{W}_{\mathrm{MF}}\right)$ also affects the oil, and after translucent we get energy of green color, which has a value $(2.19 \ldots 2.48) \mathrm{eV}$ and a frequency range $(530 \ldots 600) \mathrm{THz}$, plus the energy of the losses. Mathematically, it will look like this:

$$
\mathrm{W}^{790}{ }_{400}+\mathrm{W}_{\mathrm{MF}}=\mathrm{W}^{600}{ }_{530}+\mathrm{W}_{\mathrm{Lfr}}
$$

Thus, the energy of the MP, which acts on the oil, is determined from the previous two formulas, as:

$$
\mathrm{W}_{\mathrm{MF}}+\mathrm{W}^{510}{ }_{480}+\mathrm{W}_{\mathrm{Lfr}}=\mathrm{W}_{\mathrm{Lfr}}+\mathrm{W}^{600}{ }_{530}
$$

Here: $\mathrm{W}_{\mathrm{MF}}=\mathrm{W}^{600}{ }_{530}-\mathrm{W}^{510}{ }_{480}=(2,19 \ldots 2,48)-(1,98 \ldots 2,1)=(0,21 \ldots 0,38) \mathrm{eV}$.

Therefore, under the action of MF magnetic induction of $0.3 \mathrm{~T}$ on oil M10G2k, the amount of energy with which the MF acts on oil is $(0.21 \ldots 0.38) \mathrm{eV}$. 

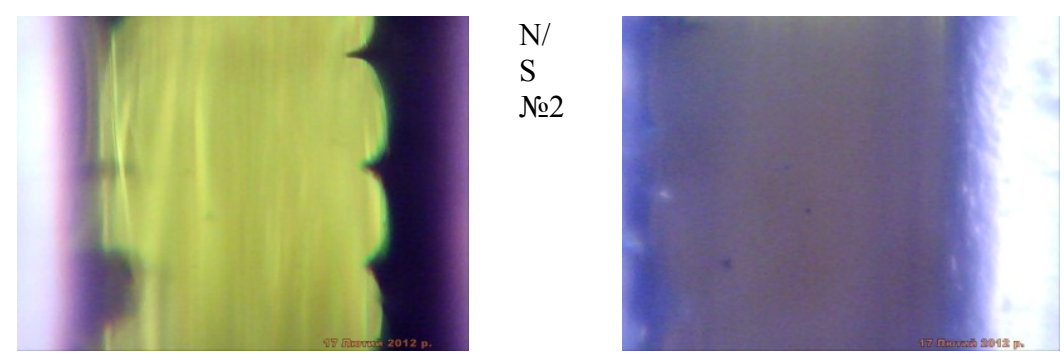

$\mathrm{N} / \mathrm{S}$

№1

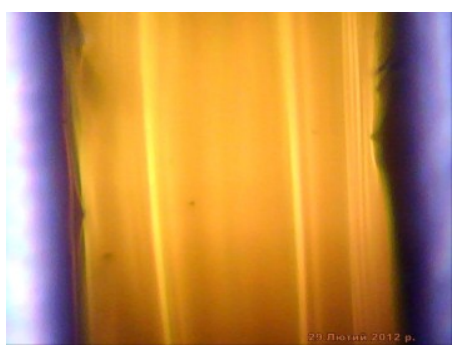

№0 S-N
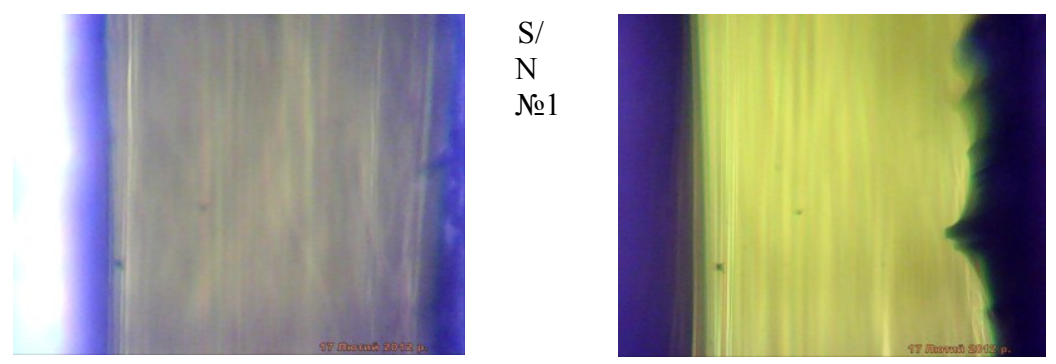

S-

$\mathrm{N}$

№2

Fig. 7. The results of studies of the change in the energy state of mineral oil M10G2k, which is under the action of a permanent magnet MF with intensity $B=0.3 \mathrm{Tl}$, by passing a beam of white light through it

To determine the percentage contribution of MF energy to oil, the energy of orange color, without the action of MF $(1.98 \ldots 2.1) \mathrm{eV}$, is taken as $100 \%$. Under the action of MF, the green color $(2.19 \ldots 2.48) \mathrm{eV}$ for $\mathrm{x} \%$. We get the following proportion:

$$
\begin{gathered}
(1,98 \ldots 2,1)-100 \% \\
(2,19 \ldots 2,48)-\mathrm{x} \%
\end{gathered}
$$

After calculations, we obtain that the percentage contribution of MF energy to oil is $11 \%-$ $11.8 \%$.

The change in the energy state of the system is reflected in the tribological parameters of the friction pair. Tribological studies were carried out according to the finger-plane scheme following the procedure described in [17]. The normal load was $1 \mathrm{~kg}$ per Hertz contact, the speed was $0.1 \mathrm{~m} / \mathrm{s}$. Friction pair: WX15 steel - LS59-1 alloy. Wearing of steel (regardless of the direction of the MF) is characterized by initial wear, but when the energy component changes, the processes of repairing the friction surface of steel $\amalg X 15$ take place. The results of the experiment are shown in Fig. 8. 


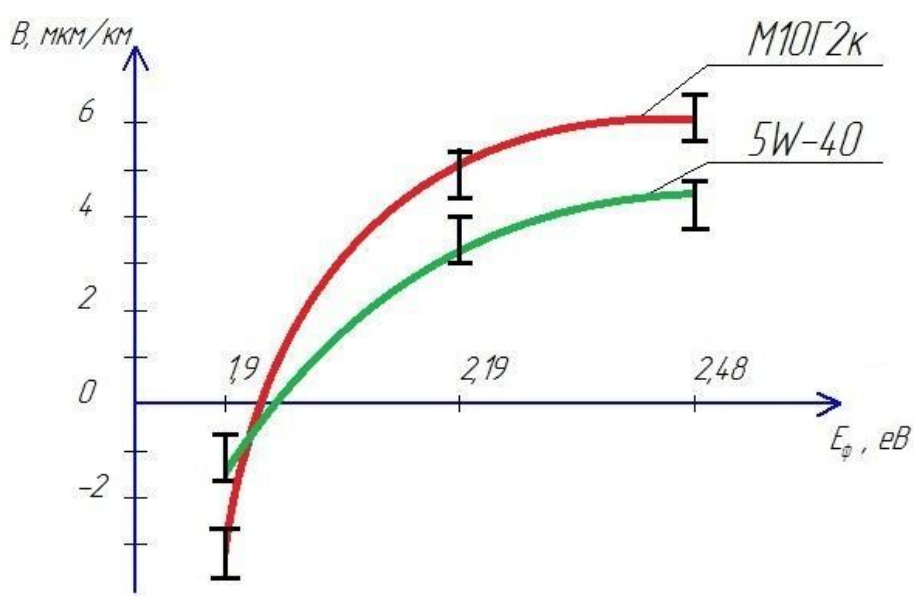

Fig. 8. Dependence of the level of wear on the value of the photon energy of light in oil

Thus, the dependence of the level of wear on the amount of energy of the oil shows that with an increase in the energy state of the oil, the wear of the material during friction decreases and goes into repair conditions. It has been established that the influence of MF on the antiwear properties of the oil is extremely positive, namely: the level of energy of the oil increases, the level of wear during friction decreases and other operational parameters do not deteriorate.

Consequently, the obtained results confirm the relevance of using the MF effect on the working environment during friction.

As a result of the experimental studies found that:

- treatment of aviation fuel «TC-1» and gasoline A-92 by EMF leads to an improvement in their antiwear properties;

- at the same values of sliding speeds and the traveled distance, the mass wearing of samples in the «TC-1» accumulated in the EMF-produced aviation fuel «TC-1» is 3.5 times less than that accumulated in the basic aviation fuel. For samples worked out in EMF-treated gasoline A-92, 2.5 times less than those worked out in base gasoline;

- it was established that the friction coefficient during lubrication of contact with jet fuel «TC-1», treated with an electromagnetic field is 1.3 times less compared to the friction coefficient obtained in «TC-1» in the delivery condition;

- a general view of the friction surfaces shows that the accumulated tribological films on friction surfaces, which worked in the EMF-treated «TC-1» fuel and A-92 gasoline, are more uniform and dense, compared with similar parameters of the samples working in the same media in the delivery condition;

- the energy aspects of the interaction of the oil with the MF, namely the amount of energy with which the MF acts on the oil is $(0.21 \ldots 0.38) \mathrm{eV}$ or $11 \%-11.8 \%$;

- during the course of research, it has been established that with an increase in the photon energy, the level of wear decreases, and this makes it possible to adjust the wear rate of friction surfaces in the media of processed MFs;

- it is established that the higher the frequency, the greater the activation energy of the oil, respectively, increases the reliability of the interaction of the oil with the friction surface, which in turn is also activated at the points of actual contact. 


\section{PЕФЕРАТ \\ Ігор Трофімов, Михайло Свирид, Олена Матвєєва, Олександр Сидоренко \\ Наиіональний авіачійний університет, troffi@ukr.net, svirid mn@ukr.net}

\section{ВПЛИВ ЕЛЕКТРОМАГНІТНОГО ОЧИЩЕННЯ ПАЛИВ ТА ОЛИВ НА ФОРМУВАННЯ ЗНОСОСТІЙКОСТІ ФРИКЦІЙНИХ ПАР}

У статті проаналізовано вплив електромагнітної обробки палив i олив на формування зносостійкості пар тертя, подано результати деяких досліджень у цій галузі. Основною метою дослідження було поліпшення експлуатаційних властивостей палив електрофізичною обробкою, яка відбувалася при їх пропущенні через електромагнітне поле, аналіз впливу магнітного поля на зміну енергетичного стану змащувальних середовищ. У роботі використано комплекс для вивчення трибологічних характеристик паливно-мастильних матеріалів, який дає можливість робити фотографічні знімки і відеозйомку поверхонь у динамічному режимі. Представлена методика обробки палив електромагнітним полем дозволяє досягти покращення їх протизносних властивостей, зниження коефіцієнта тертя, отримання більш рівномірних і щільних окисних плівок на поверхнях тертя. Результати дослідження можуть бути застосовані в галузі машинобудування для підвищення надійності деталей паливних систем, вони можуть бути використані експертами 3 трибології, хімотології, фахівцями у сфері експлуатації паливних і змащувальних систем наземної й авіаційної техніки. Прогнози щодо розвитку об'єкта вивчення - продовження досліджень 3 впливу силових полів на протизносні властивості пально-мастильних матеріалів, а також можливість контролювати та регулювати електромагнітними полями параметри зношування.

Ключові слова:надійність, електрофізична обробка, електромагнітне поле, паливо, фотон, зносостійкість, протизносні властивості, коефіцієнт тертя, поверхня тертя, вторинні структури.

\section{PЕФЕРАТ \\ Игорь Трофимов, Михаил Свирид, Елена Матвеева, Александр Сидоренко \\ Наииональний авиачионный университет, troffi@ukr.net, svirid_mn@ukr.net}

\section{ВЛИЯНИЕ ЭЛЕКТРОМАГНИТНОЙ ОЧИСТКИ ТОПЛИВ И МАСЕЛ НА ФОРМИРОВАНИЕ ИЗНОСОСТОЙКОСТИ ФРИКЦИОННЫЕ ПАР}

В даной статье проанализировановлияние электромагнитной обработки топлив и масел на формирование износостойкости пар трения,представлено результаты некоторых из наших исследований в этой области. Основной целью исследования было улучшения эксплуатационных свойств топлив электрофизической обработкой, которая происходила при их пропускании через электромагнитное поле, анализ влияния воздействия магнитного поля на изменение энергетического состояния смазывающих сред. В работе использован комплекс для изучения трибологических характеристик горюче-смазочных материалов, который позволяет делать фотографические снимки и видео съемку поверхностей в динамическом режиме. Представленная методика обработки топлив электромагнитным полем позволяет достичьулучшение их противоизносных свойств, снижения коэффициента трения, получение более равномерных и плотных окисных плёнок на поверхностях трения. Результаты исследований могут быть применены в отраслимашиностроения для повышения надёжности деталей топливных систем, они могут быть использованыэкспертами трибологами, химмотологами, а также специалистами в области эксплуатации топливных и смазывающих систем наземной и авиационной техники. Прогнозы по развитию объекта изучения- продолжение исследований по влиянию силовых полей на противоизносные свойства горюче-смазочных материалов, а такжевозможность контролировать и регулировать электромагнитными полями параметры изнашивания.

Ключевые слова: надёжность, электрофизическая обработка, электромагнитное поле, топливо, фотон, износостойкость, противоизносные свойства, коэффициент трения, поверхность трения, вторичные структуры.

\section{ABSTRACT \\ Igor Trofymov, Mykhailo Svyryd, Olena Matveyeva, Oleksandr Sydorenko National Aviation University, troffi@ukr.net,svirid_mn@ukr.net \\ INFLUENCE OF ELECTROMAGNETIC TREATMENT OF FUELS AND OILS ON THE FORMATION OF WEAR RESISTANCE OF FRICTION PAIRS}

This article discusses the effect of electromagnetic processing of fuels and oils on the formation of wear resistance of friction pairs and presents the results of some of our research in this area. The main goal 
of the research was to improve the performance properties of fuels by electrophysical treatment, which occurred when they were passed through an electromagnetic field and to study the effect of the influence of a magnetic field on the change in the energy state of lubricants. In the work, a complex was used to study the tribological characteristics of fuels and lubricants, which allows you to take photographs and video images of surfaces in a dynamic mode. The presented method of treating fuels with an electromagnetic field makes it possible to acheivean improvement in their anti-wear properties, a decrease in the friction coefficient, and a more uniform and dense oxide films on the friction surfaces. The research results can be applied in the field of mechanical engineering to increase the reliability of parts of fuel systems, they can be applied by experts by tribologists, chemotmologists, as well as experts in the field of operation of fuel and lubricating systems of ground and aviation equipment. Predictive assumptions on the development of the object of study - the continuation of research on the effect of force fields on the antiwear properties of fuels and lubricants, as well as the ability to control and regulate wear parameters by electromagnetic fields.

Key words: reliability, electrophysical treatment, electromagnetic field, fuel, photon, wear resistance, antiwear properties, coefficient of friction, surface of friction, secondary structures.

\section{REFERENCES}

1. Increasing the resource of technical systems through the use of electric and magnetic fields: monographs / [E. E. Alexandrov, I. A. Kravets, E. P. Lysikov et al.]. - Kharkov: NTU „KhPI”, 2006. - 544 p.

2. Kravets, I. A. Reparative regeneration of tribo systems / I. A. Kravets - T.: Berezhansky Agrotechnical Institute Publishing House, 2003. -284 p.

3. Evdokimov, A.Yu. Lubricants and environmental problems: textbook, manual / A. Yu. Evdokimov, I.G. Fuchs, T.N. Shabalina. - M.: GUP Oil and Gas, 2000. -424 p.

4. Diha $O$. The Rosrakhunkovo-experimental research of tribological authorities of the masters of mathematics // O. Diha, A. Kuzmenko, V. Mokritsky - Machinstvo. - 2001. - №7. - P. 29-32.

5. Lisikov E.M. Partitioning the resource of tribo-technical systems by means of the grid for the electrostatic field to the masters of materials / E.M. Lisikov // Tekhnika ta vikonya technology Budivnich, Koliynykh and perevaltazhvalnyh robit on transport: Zb. sciences. prat Iss. 58. - Kharkiv: UkrDAZT, 2004. - P. 5-10.

6. Tretyakov I.G. The effect of electromagnetic treatment on the antiwear properties of individual hydrocarbon compounds / I.G. Tretyakov, Yu.I. Korolenko // Problems of Aviation Chemotology. Mezhvuz. Sat, Issue 2. - Kiev, 1978. - P. 141-144.

7. Morozov V.I. Effect of electrophysical effects on the performance properties of diesel fuel / V.I. Morozov, Ya.E. Belokon, A.I. Okocha. // Studies of the processes of preparation, application and quality control of aviation fuel and special liquids. - 1992. - № 5. - P. 94-98.

8. Bazhenov Yu.V. Triboelectrization of oil and diesel fuel // Yu.V. Bazhenov, Yu.A. Mikiporis, A.N. Pavlov // Friction and lubrication in machines and mechanisms. - 2006. - № 10. - P. $24-27$.

9. Trofimov I. L. Pidvischennya tribotehnichnyh power of paliv and olive field of electricity / I. L. Trofimov // Questions of chemistry and chemical technology. - 2010. - № 3. - P. 132-137.

10. Podgorkov V.V. The carrying capacity of magnetic fluids / V.V. Podgorkov // Friction and wear. -1990. - Vol. 11. - № 2. - P. 359-361.

11. Sudbury A. Quantum mechanics and particle physics / A. Sudbury. - M.: Mir, 1989. - 488 p.

12. Boom A. Quantum mechanics: fundamentals and applications / A. Boum. - M.: Mir, 1990. -720 p.

13. Trofimov I.L. Systems and means of motor transport (selected problems), by Politechnika Rzeszowska / I.L. Trofimov, N.N. Zakharchuk. - Rzeszow, Poland. - P. 295-301.

14. Pat.72848 Ukraine. F02M 27/00, F02M 27/04 (2006.01). Spalib processing paliva / Andrievsky A.P., Matveeva O.L., Nechosov V.V.; applicants and vlasniki Andriєvsky A.P, Matveeva O.L., Nechosov V.V. - № u2012 03103; declared 03/16/2012; publ. 27.08.2012, Bull. №16.

15. Pat.72858 Ukraine. B01D 36/00, F02M 27/04 (2006.01). Filipr-activator paliva / Andrievsky A.P., Matveeva O.L., Nechosov V.V.; applicants and vlasniki Andrievsky A.P, Matveea O.L., Nechosov V.V. - № u2012 03245; declared 03/19/2012; publ. 27.08.2012, Bull. №16.

16. Svirid M.M. The complex for the progress of the tribotechnical parameters of the institute / M.M. Svirid, V.G. Paraschanov, A.V. Onishchenko // Problem rubbing that znoshuvannya. - 2006. - No. 45. - P. 204-209.

17. Pat. № 70877. Ukraine. G01N 3/56. Device for study of friction surfaces in permanent uniform and nonuniform magnetic field / Svirid M.M., Kudrin A.P., Kravets I.A., Priymak L.B., Borodiy V.M. - № u201115161; declared 12/21/2011. Publ.25.06.2012, Bull. № 12 - 5 p. 